De Jure: Jurnal Hukum dan Syar'iah

Vol. 12, No. 1, 2020, h. 86-101

ISSN (Print): 2085-1618, ISSN (Online): 2528-1658

DOI: http://dx.doi.org/10.18860/j-fsh.v12i1.8700

Available online at http://ejournal.uin-malang.ac.id/index.php/syariah

\title{
A. Djazuli's Thinking Regarding Hifžu al-Ummah: Dismissing the Entangled Bureaucracy to Commemorate the Era of Society $\mathbf{5 . 0}$
}

\author{
Sabarudin Ahmad \\ IAIN Palangka Raya, Indonesia \\ sabarudin.ahmad@iain-palangkaraya.ac.id \\ Novita Anggraeni \\ IAIN Palangka Raya, Indonesia \\ Andrian Kukuh Pambudi \\ IAIN Palangka Raya, Indonesia
}

\section{Abstract:}

Nations in the world have been preoccupied with new ideas in the form of the society 5.0 era, while this nation is still trying to release the entangled bureaucracy. The government's efforts in reforming the bureaucracy with its various standards have not been able to produce satisfactory results. Therefore, this study seeks to contribute ideas by examining the thoughts of A. Djazuli about hifzu al-ummah on this issue. This research is normative legal research. The analytical method used is the method of content analysis. The results of this study indicate that maqāsid syari'ah has been oriented to individual problems, so that they pay less attention to humans in the community. Hifzu alummah as the development of maqāșid syari'ah places this bureaucratic problem in the category of maqassid al-hajiyat. The complicated bureaucracy does not damage human life but is very difficult. The bureaucratic system in Indonesia must be directed at a modern system with artificial intelligence in welcoming the era of 5.0 society.

Keywords: bureaucracy; hifzu al-ummah; era of society 5.0

\section{Abstrak:}

Bangsa-bangsa di dunia telah disibukkan dengan gagasan baru berupa era society 5.0, sedangkan bangsa ini masih berusaha melepaskan jeratan birokrasi yang berbelit. Upaya pemerintah dalam mereformasi birokrasi dengan berbagai standarisasinya belum mampu membuahkan hasil yang memuaskan. Oleh karena itu, penelitian ini berusaha memberikan kontribusi pemikiran dengan mengkaji pemikiran A. Djazuli tentang hifz al-ummah terhadap permasalahan ini. Penelitian ini merupakan penelitian hukum normatif. Metode analisis yang digunakan ialah metode analisis isi. Hasil penelitian ini menunjukkan bahwa 
maqashid syariah selama ini berorientasi pada persoalan individual, sehingga kurang memperhatikan manusia dalam komunitas. Hifz al-ummah sebagai pengembangan dari maqashid syariah menempatkan persoalan birokrasi ini dalam kategori maqashid al-hajiyat. Birokrasi yang berbelit tidak sampai merusak kehidupan manusia tetapi sangat menyulitkan. Sistem birokrasi di Indonesia harus diarahkan pada sistem modern dengan artificial intellegence dalam menyongsong era society 5.0.

Kata Kunci: birokrasi; hifžu al-ummah, era sosial 5.0

\section{Introduction}

Indonesia as a developing country cannot be separated from various national problems. One of the important things is the problem of bureaucracy. In simple terms, bureaucracy can be interpreted as a government system in terms of public services. ${ }^{1}$ This problem is crucial because in the course of this nation it has always been an endless conversation. Bureaucracy in Indonesian government often has a negative connotation in people's minds. The negative stigma is not only in the local community, even the foreign community believes that. ${ }^{2}$ When they deal with the government, document management is always complicated, unfriendly, unfair, not transparent, and tends to complicate matters. ${ }^{3}$ However, for those who have links in government institutions, or when there is a reward for their business, then all their affairs will be easy and quickly completed. This is a fact that cannot be denied. ${ }^{4}$ Yusriadi said that related to this problem:

So far, many bureaucrats have more traditional and even feudalistic behavior. Feudal culture like this fosters a culture of nepotism, so that the community interests should be given fairly and equally are set aside by factors of closeness

\footnotetext{
${ }^{1}$ Gatot Pramuka, 'Masalah Birokrasi Sebagai Pelayan Publik', Masyarakat, Kebudayaan Dan Politik 20, no. 1 (2007).

2 Preface from Azwar Abubakar in Rusfi Yunairi, Abdul Hakim, and Eko Prasojo, Pemimpin dan Reformasi Birokrasi: Catatan Inspiratif dan Alat Ukur Kepemimpinan dalam Implementasi Reformasi Birokrasi (Jakarta: Kementrian Pendayagunaan Aparatur Negara dan Reformasi Birokrasi, 2013), xvii.

${ }^{3}$ Rina Martini, Buku Ajar Birokrasi Dan Politik (Semarang: LPPMP Universitas Diponegoro, 2012), 8. ${ }^{4}$ Asman Abdur said this problem was influenced by the existence of six bureaucratic problems in Indonesia. First, specifically for regional goverments, the percentage of internal operational expenditure is greater than public expenditure, so that it is preoccupied with internal affairs and public affairs and public affairs are ignored. Second, the high level of corruption, evidenced by a number of facts of arrest by the KPK in various cases such as bribery, project fees, gratuities and licensing. Third, ineffectiveness and inefficiency in development management. Development planning is mostly done haphazardly, copying and pasting from previous years, so it does not focus on the outcome to be achieved. Fourth, the quality of ASN is not yet optimal, in terms of educational backgorund most are only high school graduates. Fifth, government organizations rarely seek to simplify organizational structures, and even tend to continue to form non-structural institutions that have the task of coinciding with functional institutions. Sixth, the quality of public service is not as expected. Poor public services tend to give the impression that government does not care about the community. Yustinus Paat, 'Ini Enam Penyakit Birokrasi Di Indonesia', accessed 29 June 2020, https://www.beritasatu.com/nasional/485766-ini-enam-penyakit-birokrasi-di-indonesia.
} 
or kinship. Only people who have acess to this closeness get a job position or for the people can get optimal government service. ${ }^{5}$

A survey was reported, the index of integrity of public service in Indonesia was ranked 70 out of 109 countries. It is under the neighboring countries such as Timor Leste, Philippines, Malaysia and Thailand. The survey in the administrative service component was the worst by ranking $97 .{ }^{6}$ Karl D. Jackson said that bureaucracy in Indonesia is a bureaucratic polity model. This model is an accumulation of power to the state and removes the role of society from the political and government spheres. ${ }^{7}$ The government has tried to overcome these problems. Several times the change of leadership has been attempted in such a way towards the bureaucratic system. Finally, during the presidency of Joko Widodo, he continued the effort called bureaucratic reform which had been initiated since the era of Susilo Bambang Yudhoyono (SBY).

Basically, bureaucratic reform is an attempt to make fundamental reforms and changes to the system of government administration. Various problems and obstacles in the implementation must be reorganized or updated. This reform was carried out in order to realize good governance. The efforts made are fundamental, comprehensive, and systematic, so that the goals and objectives can be achieved effectively and efficiently. However, this bureaucratic reform is a process that is carried out in a gradual and sustainable manner, in the sense that it is not a radical or revolutionary action. ${ }^{8}$ The seriousness of the government in this effort led to the addition of names in the form of the ministry of the utilization of state apparatus and bureaucratic reform that had begun since the era of President Susilo Bambang Yudhoyono. However, the implementation has not been satisfactory. The existence of inequality in public services becomes homework that must be completed.

Some researchers have tried to examine bureaucratic problems in Indonesia, such as Mohammad Thahir Haning ${ }^{9}$ and Yusriadi ${ }^{10}$, who analyzed bureaucratic problems and their obstacle. In addition, Muhtar Haboddin and Ahmad Imron

\footnotetext{
${ }^{5}$ Yusriadi Yusriadi, 'Reformasi Birokrasi Indonesia: Peluang dan Hambatan', Jurnal Administrasi Publik: Public Administration Journal 8, no. 2 (21 December 2018): 184, https://doi.org/10.31289/jap.v8i2.1824.

6 Mohammad Thahir Haning, 'Reformasi Birokrasi di Indonesia: Tinjauan Dari Perspektif Administrasi Publik', JAKPP (Jurnal Analisis Kebijakan \& Pelayanan Publik) 4, no. 1 (12 January 2019): 26, https://doi.org/10.31947/jakpp.v4i1.5902.

${ }^{7}$ Lili Romli, 'Masalah Reformasi Birokrasi', Civil Service Journal 2, no. 2 November (2008): 2, https://jurnal.bkn.go.id/index.php/asn/article/view/149.

${ }^{8}$ Kementerian Pemberdayaan Aparatur Negara dan Reformasi Birokrasi, 'Reformasi Birokrasi', Kementerian Pendayagunaan Aparatur Negara dan Reformasi Birokrasi, accessed 29 June 2019, https://www.menpan.go.id/site/reformasi-birokrasi/makna-dan-tujuan.

${ }^{9}$ Haning, 'Reformasi Birokrasi di Indonesia'.

${ }^{10}$ Yusriadi, 'Reformasi Birokrasi Indonesia'.
} 
Rozuli, ${ }^{11}$ Anastasia Reni Widyastuti, ${ }^{12}$ Fatkhuri, ${ }^{13}$ and Irfan Setiawan ${ }^{14}$ focused studies on bureaucracy and corruption in Indonesia. The researchers examined bureaucratic problems from various aspects of law and government. The research direct this research to examine the problem of bureaucracy in Islamic legal thinking, especially regarding Maqūssid syarīah was initiated by A. Djazuli. Some researchers have also examined the thoughts of A. Djazuli, such as Widyawati and Syahrial Dedi. But, they study ideas of A. Djazuli in general, about the concept of hifzu alummah. Base on that, the author's research has a place in the concept area directed at a solutive study of bureaucratic problems. Therefore, this research is important as a first step in integrating the concept of hifz ummah with bureaucratic problems in Indonesia.

Hifzu al-ummah is a contemporary idea of Islam about order. One of the initiators was A. Djazuli, a professor from UIN Sunan gunung Jati, Bandung. This study discusses in depth and comprehensively the hifzu al-ummah as a contribution to thinking about the problems above. To optimize this research, it will be integrated with the development of the era society 5.0. This research is included in the category of library research. Other terms in law, this research is also called normative legal research. ${ }^{15}$ law is conceptualized as written law (law in book) not law in its implementation concept (law in action). ${ }^{16}$ The primary material in this study was Fiqh Siyasah by A. Djazuli, while secondary material consisted of relevant books and journals, and supplemented with tertiary material in the form of dictionaries. While the analytical method used in this study is the content analysis method. ${ }^{17}$

\section{Biography of A. Djazuli}

Atjep Djazuli was born on March 25, 1938 in Kubang, Cianjur, West Java. His father named Djunaidi, and his mother named Jubaedah. He was the last of nine children. Education from A. Djazuli in elementary school took twice, morning in public schools and in the afternoon at the madrasa. Subsequently in 1952, he continued his studies in the First Religion Teacher Education (PGAP) in Bogor until 1956. He was later accepted as a prospective judge in a religious court which required him to attend the State Islamic Judge Education (PHIN) in Yogyakarta for three years. After that, he returned to Cianjur to start becoming a judge at the religious court institution. In 1961, he decided to continue his education at the Bachelor (S1) level of Islamic Law at the Faculty of Sharia, IAIN Sunan Kalijaga, Yogyakarta.

\footnotetext{
11 Muhtar- Haboddin and Ahmad Imron Rozuli, 'Birokrasi, Korupsi, Dan Kekuasaan', Jurnal Transformative 3, no. 1 (22 March 2017): 1-14.

12 Anastasia Reni Widyastuti, 'Disfungsionalisasi Birokrasi Sebagai Kendala Dalam Pemberantasan Korupsi', Yustisia Jurnal Hukum 4, no. 3 (1 December 2015): 683-99, https://doi.org/10.20961/yustisia.v4i3.8700.

13 Fatkhuri Fatkhuri, 'Korupsi Dalam Birokrasi Dan Strategi Pencegahannya', Jurnal Ilmiah Manajemen Publik Dan Kebijakan Sosial 1, no. 2 (16 April 2018): 65-76, https://doi.org/10.25139/jmnegara.v1i2.784.

${ }^{14}$ Irfan Setiawan, 'Mengikis Perilaku Korupsi Pada Birokrasi Pemerintahan', Jurnal Ilmu Pemerintahan Widya Praja 42, no. 1 (1 June 2016): 29-29, https://doi.org/10.33701/jipwp.v42i1.140.

${ }^{15}$ Soerjono Soekanto and Sri Mamudji, Penelitian Hukum Normatif (Jakarta: RajaGrafindo Persada, 2003), 13-14.

${ }^{16}$ Zainal Asikin and Amiruddin, Pengantar Metode Penelitian Hukum (Jakarta: Rajawali Pers, 2013), 118.

${ }^{17}$ Emzir, Analisis Data: Metodologi Penelitian Kualitatif/ Emzir (Jakarta: Rajawali Press, 2010), $283-84$.
} 
After graduating he was appointed as a lecturer at the Faculty of Sharia, IAIN Sunan Gunung Djati, Bandung. Not stopping there, in 1972 he continued his education in a non-degree course at the Postgraduate IAIN Yogyakarta. After returning, he was appointed dean for three years (1973-1976). In addition to IAIN Bandung, he also teaches at the Academy of Domestic Administration (now IPDN), Nusantara Islamic University (UNINUS), and Galunggung Law School. The subject of his expertise is Islamic law or sharia. ${ }^{18}$

A Djazuli is also active in other institutions such as the Indonesian Ulema Council (MUI), West Java Islamic Community Association (PUI), Mathlaul Anwar, Tarjih Council and Tajdid Muhammadiyah of West Java. He was also a member of the Expert Council of the Indonesian Muslim Intellectual Association of West Java Province. Although he is an expert in Islamic political science, has never been involved in political practice for certain positions. ${ }^{19}$ A Djazuli was inaugurated as a professor of Islamic law in 1995. Uniquely he has not attended a doctoral program at any university. For his services to IAIN Bandung (now UIN Bandung), he was awarded the honorary causa doctorate in 2009 and died on April 25, 2015. A Djazuli is a productive academic. He wrote hundreds of papers and wrote as many as 10 books. One of the books that was studied in this study was Fiqh Siyasah. He was one of the initiators of the hifzu al-ummah as the development of maqāsid syarīah..

\section{Problems with Bureaucracy in Indonesia}

Bureaucracy comes from the French bureau which means office or writing desk, and Greek cratein which means regulating. ${ }^{20}$ In the Dictionary of Indonesian Language it is interpreted as "a system of government run by government employees because it has adhered to the hierarchy and levels of office". ${ }^{21}$ Peter M. Blau and W. Meyer said that bureaucracy is a type of organization that is intended to achieve administrative tasks by coordinating systematically the work of many members of the organization. ${ }^{22}$ The term bureaucracy is often associated with government, even though Max Weber's bureaucracy can also occur in non-governmental organizations. Bureaucracy is a system for managing a large organization in order to obtain efficient, rational, and effective management. ${ }^{23}$ However, it is generally understood that the term bureaucracy refers to the government bureaucracy. In this study, the focus of bureaucratic problems also refers to the government bureaucracy.

Bureaucratic problems are very complex. Syafuan Rozi regretted the situation, according to him the bureaucracy was relatively a political instrument or as a tool to achieve the logic of power, namely by gaining, improving, maintaining and expanding power for certain actors, elites or political groups. The ideal bureaucracy should make it a facilitator and professional public service for all groups without

\footnotetext{
${ }^{18}$ Widyawati, 'Hifz Al-Ummah Sebagai Tujuan Syariah: Kontribusi Pemikiran Hukum Islam Prof. a. Djazuli', in The Contribution of Indonesia Islam to The World Civilization (Annual International Conference on Islamic Studies (AICIS) 2016, IAIN Raden Intan Lampung, 2016), 3, http://iainsurakarta.ac.id/aicis/2016/paralel-sessions/.

${ }^{19}$ Widyawati, 5.

${ }^{20}$ Delly Mustafa, Birokrasi Pemerintahan (Bandung: Alfabeta, 2013), 1.

21 Kementerian Pendidikan dan Kebudayaan, 'Arti Kata Birokrasi', accessed 29 June 2020, https://kbbi.kemdikbud.go.id/entri/birokrasi.

${ }_{22}^{2}$ Martini, Buku Ajar Birokrasi Dan Politik, 8.

${ }^{23}$ Miftah Thoha, Birokrasi pemerintah Indonesia di era Reformasi (Jakarta: Kencana, 2011), 15.
} 
discriminating between the elite and ordinary people. ${ }^{24}$ Bureaucracy is indeed like a knife, on the one hand it can be beneficial, but it can also backfire when it is not carried out properly. Agus Pramusinto in the introduction to the book of the Bureaucrats (not) Corruption Servants confirmed that:

Bureaucracy in developing countries largely determines the success of development. Judging from the size of the structure, the strength of the organization, the mastery of the budget and the number of officials, the bureaucracy is an attractive political arena for the struggle for business. With such an illustration, bureaucracy is a source of strength as well as a source of problems in development practices in developing countries in general, including Indonesia. One of the biggest problems with bureaucracy in Indonesia is corruption. ${ }^{25}$

One of the problems inherent in bureaucracy is corruption. Corruption is an important issue that is very disturbing bureaucratic reform in Indonesia as previously explained. The latest data on corruption in Indonesia according to Indonesia Corruption Watch (ICW) in 2018, the country suffered a loss of 9.9 trillion rupiah. ${ }^{26}$ In the same year, Indonesia was ranked 89th of the Corruption Perseption Index (CPI) with a score of 38 from the $0-100$ range. ${ }^{27}$ Corruption occurs almost at every level of power, both executive, legislative and judicial. Starting from the Setya Novanto case, ${ }^{28}$ buying and selling positions at the Ministry of Religion of the Republic of Indonesia by Romahurmuziy, ${ }^{29}$ up to the case of the hand-arrest operation (OTT) governor of Riau Archipelago on July 10, 2019 ago. ${ }^{30}$ Likewise, in the scope of judicial power from the period of 2012 there were at least 20 judges involved in corruption cases. ${ }^{31}$ This fact is very alarming. Corruption has become a severe disease that always undermines the country

Cases of regional heads revealed by corrupt actions cannot be separated from the complexity of bureaucratic problems. The amount of costs incurred to become

\footnotetext{
${ }^{24}$ Syafuan Rozi, Zaman Bergerak, Birokrasi Dirombak: Potret Birokrasi Dan Politik Di Indonesia (Yogyakarta: Pustaka Pelajar, 2006), 2.

${ }^{25}$ Dwiyanto Indiahono, Birokrat [Bukan] Pelayan Koruptor: Telaah Korupsi, Demokrasi Dan Pro-Poor Policy Di Era Reformasi (Jakarta: Gava Media, 2016), 1.

${ }^{26}$ Dylan Aprilialdo Rachman, 'ICW: Kerugian Negara Akibat Korupsi Pada 2018 Capai Rp 9,29 Triliun', $\quad 29$ accessed September 2019, https://nasional.kompas.com/read/2019/04/28/15294381/icw-kerugian-negara-akibat-korupsipada-2018-capai-rp-929-triliun?page $=$ all.

${ }^{27}$ Ari Saputra, 'Indonesia Ranking 89 Indeks Persepsi Korupsi Dunia', detiknews, accessed 29 June 2020, https://news.detik.com/foto-news/d-4405951/indonesia-ranking-89-indeks-persepsi-korupsidunia.

${ }^{28}$ Haris Fadhil, 'Cicil Hukuman USD 7,3 Juta, Berapa Sisa "Utang” Novanto ke Negara?', detiknews, accessed 29 June 2020, https://news.detik.com/berita/d-4297856/cicil-hukuman-usd-73-jutaberapa-sisa-utang-novanto-ke-negara.

${ }^{29}$ Afdal, 'Berikut Data Kasus Korupsi dari 2018 Hingga Maret 2019', Fajar Indonesia Network (blog), 1 April 2019, https://fin.co.id/2019/04/01/berikut-data-kasus-korupsi-dari-2018-hingga-maret2019/.

${ }^{30}$ Hari Widowati, 'Proyek Reklamasi Gurindam 12 Yang Menjerat Gubernur Kepri - Berita Katadata.Co.Id', accessed 29 June 2020, https://katadata.co.id/berita/2019/07/11/proyekreklamasi-gurindam-12-yang-menjerat-gubernur-kepri.

${ }^{31}$ Abba Gabrillin, 'Sejak 2012, Ada 20 Hakim Tersangkut Kasus Korupsi', KOMPAS.com, accessed 29 June 2020, https://nasional.kompas.com/read/2019/05/07/10483411/sejak-2012-ada-20hakim-tersangkut-kasus-korupsi.
} 
the head of the region requires him to reap financial benefits by utilizing his power. Apart from playing government projects, it can also be generated from buying and selling positions by placing certain tariffs for certain positions. Dwiyanto said that the game of buying and selling positions made bureaucrats truly become loyal servants of corruptors. The impact of the game not only affected the actors, but also the community. He further explained that there were at least two negative effects of the problem.

First, public affairs lose the opportunity to be managed by good people... The second impact is the birth of corrupt officials. Bribing behavior to get a position will certainly have implications for efforts to pay off the costs of sitting in positions... Officials can play in public services and policies in their control. Negative relations between public officials and market participants are very close and widely in the dynamics of corruption in the bureaucracy. The dark financial benefits obtained from a position have become common knowledge. ${ }^{32}$

The problem of bureaucracy above is a worrying reality and a concern. Various efforts have been made including bureaucratic reform, but the results have not been satisfactory. Therefore, the authors try to contribute to the thought to deal with these problems as will be described in the next discussion.

\section{A. Djazuli's Thinking Regarding Hifžu al-Ummah: Dismissing the Entangled Bureaucracy to Commemorate the Era of Society 5.0}

Hifzu al-ummah is the development of maqāșid syarīah. ${ }^{33}$ The maqāșid syarīah was initiated by Ash-Syatibi which includes nurturing religion (hifzu ad-din), nurturing the soul (hifzu al-nafs), nurturing offspring (hifżu al-nasl), nurturing reason (hifżu al-'aql), preserving wealth (hifžu al-māl). ${ }^{34}$ Shihabuddin Al-Qarafi in Yusuf AlQaradhawi added that one of the main points of maqāșid syañ'ah is to maintain honor (hifżu al-ird). ${ }^{35}$ Maqāșid syarī'ah continues to be developed by Islamic jurists. Yusuf AlQaradawi in Reflita adds one main theme of maqașid syañ'ah which is maintaining the environment (hifżu al-bï'ah). ${ }^{36}$ The same thing was expressed by Ali Yafie. ${ }^{37}$ The addition of hifzu al-bi'ah was driven by concerns about environmental damage that occurred in various parts of the world. Development of maqāșid syarīah does not stop there. In this paper, we examine in depth the addition of one element that is no less

\footnotetext{
${ }^{32}$ Indiahono, Birokrat [Bukan] Pelayan Koruptor: Telaah Korupsi, Demokrasi Dan Pro-Poor Policy Di Era Reformasi, 7-8.

${ }^{33}$ Maqāsid syariah in etymology means the objectives of sharia. That these goals according to Abu Ishaq Al-Syatibi are to realize human benefit both in the world and in the hereafter. Al-Syatibi's thinking about maqāșid syarīah can be seen in his book entitled Al-Muwafaqat fi Usul al-Syarīah. See Asfari Jaya Bakri, Konsep Maqasid Al-Syari'ah Menurut al-Syatibi (Jakarta: RajaGrafindo Persada, 1996), 64

${ }^{34}$ Sabarudin Ahmad, 'Hukum Aborsi Akibat Perkosaan (analisis Hukum Islam Terhadap Peraturan Pemerintah Nomor 61 Tahun 2014 Tentang Kesehatan Reproduksi )', El-Mashlahah 8, no. 2 (2018): 117, https://doi.org/10.23971/el-mas.v8i2.1321.

${ }^{35}$ Yusuf Al-Qaradhawi, Fiqh Maqashid Syariah; Moderasi Islam Antara Aliran Tekstual Dan Aliran Liberal, trans. Arif Munandar Riswanto (Jakarta: Pustaka al-Kautsar, 2014), 148.

${ }^{36}$ Reflita Reflita, 'Eksploitasi Alam dan Perusakan Lingkungan (Istinbath Hukum atas Ayat-Ayat Lingkungan)', SUBSTANTIA: Jurnal Ilmu-Ilmu Ushuluddin 17, no. 2 (11 October 2015): 148, https://doi.org/10.22373/subtantia.v17i2.4101.

${ }^{37}$ Reflita, 156.
} 
important than the seven elements as described above. The important element in question is maintaining the people (hifzu al-ummah). One important figure in this development was A. Djazuli. An academic who is concerned in thoughts that are oriented to social problems.

Maqāsid syarīah has always been oriented to individual problems. In fact, they tend to lack important human issues in the context of society. The development that is concerned with environmental issues should be appreciated. However, human problems in the context of society should receive attention too. The occurrence of various cases that hit this country, ranging from problems between the ummah and the government, especially the problem of bureaucracy, arrived at issues of disunity which threatened the integrity of the nation adding to the urgency of the discussion about the hifzu al-ummah. The discourse about hifẓu al-ummah being part of maqāșid syari'ah was pioneered by A. Djazuli in his book Fiqh Siyasah, then Wahab Afif whose thoughts were reviewed by Juhaya S. Praja. In addition, also mentioned by Asep Arifin and Nanat Fatah Natsir when reviewing Hifzu al-bi'ah. ${ }^{38}$ It can be said that studies of hifzu al-ummah are still quite rare and must continue to be developed.

The ummah comes from Arabic which has been absorbed into Indonesian into the word umat. ${ }^{39}$ Wahab Afif, one of the pioneers of hifzu al-ummah, divided the meaning of the ummah in two perspectives. First, the ummah in a normative perspective is interpreted as a formal community based on the primordial ties of a particular religion, nation or culture. Secondly, the ummah in an empirical perspective is interpreted by many people who are not limited in diversity both vertically (descent, history, and generation) and horizontally (economic, social, cultural and political). ${ }^{40}$ A. Djazuli gives meaning to the ummah in three layers. ${ }^{41}$ First, the ummah means all God's creatures, both humans and other creatures. As Allah says in the Qur'an surah Al-An'am: 38. Second, the ummah means humans as a whole, both Muslims and non-Muslims. As stated in the surah Al-Baqarah: 213. Third, the ummah means one particular human community. In this case, it is only distinguished between muslims and non-muslims. As found in surah Al-Anbiya: 92.

Hifz al-ummah as an effort to realize maqāșid syarīah is oriented towards human interests collectively. In this matter, Afrizal detailed the maqāsid syarīah classification as follows: a) Maintaining humanity (hifzu al-insan). This can be developed to safeguard world peace, international cooperation, democracy and so on; b) Maintaining the Muslims (hifžu al-ummah). This can be developed into the maintenance of ukhuwah Islamiyah, international relations of Islamic Countries; c) Maintaining the state (hifzu al-daulah). This can be developed into the freedom to practice Islam in a state system, the formation of a political System; d) Caring for the community (hifž al-mujtama). This can be developed into the preservation of

\footnotetext{
${ }^{38}$ Syahrial Dedi, 'Perluasan Teori Maqashid Al-Syari'ah: Kaji Ulang Wacana Hifdz Al-'Ummah A. Djuzuli | Dedi | Al-Istinbath : Jurnal Hukum Islam', Al Istinbath Jurnal Hukum Islam 1, no. 1 (2016): 61, http://dx.doi.org/10.29240/jhi.v1i1.72.

${ }^{39}$ Umat in the Big Dictionary of Indonesian Language are interpreted in two meanings, first the people mean the followers of a religion. second, umat means human beings in the sense of humanity. Kementerian Pendidikan dan Kebudayaan, 'Arti Kata Umat', accessed 29 June 2020, https://kbbi.kemdikbud.go.id/entri/birokrasi.

${ }^{40}$ Juhaya S. Praja, Teori Hukum Dan Aplikasinya (Bandung: Pustaka Setia, 2011), 165.

${ }^{41}$ A. Djazuli, Fiqh Siyasah: Implementasi Kemaslahatan Ummat Dalam Rambu-Rambu Syariah (Jakarta: Kencana, 2013), 258.
} 
culture, adat (urf), local values in the context of the universality of Islam; e) Caring for the family (hifzu al-nasl/usrah). This can be developed into the maintenance and development of the family system, maintenance of the system and things related to it. ${ }^{42}$ The classification by Afrizal above boils down to efforts to preserve the ummah (hifzu al-ummah). That human beings in the form of a community have a significant urgency to protect their rights. This is to offset the existence of individual rights in the community. So that by fulfilling these rights in a balanced manner, human benefit will be realized.

${ }^{42}$ Afrizal Ahmad, 'Reformulasi Konsep Maqashid Syar'iah; Memahami Kembali Tujuan Syari'at Islam Dengan Pendekatan Psikologi', Hukum Islam 14, no. 1 (2014): 47, https://doi.org/10.24014/hi.v14i1.988. 


\section{Hifżu al-Ummah: Dismissing the Entangled Bureaucracy to Commemorate the Era of Society 5.0}

The government's efforts in overcoming bureaucratic problems are by initiating bureaucratic reform. Since the era of Susilo Bambang Yudhoyono (SBY), a special ministry has been formed on bureaucratic reform. Then it was continued by the next government in Joko Widodo's era. SBY said that the obstacles to development in Indonesia were bureaucracy, infrastructure and corruption. Fundamentally improving the bureaucracy must be done at all levels, both central and regional. In the context of policy, bureaucratic reform has been accommodated in the 2005-2025 National Long Term Development Plan (RPJN). In the document, the direction of national policies and strategies is regulated in the field of apparatus development to increase its professionalism. This design is outlined and detailed in a grand design of bureaucratic reform as a direction for implementing national bureaucratic reform. ${ }^{43}$

This grand design is a follow up to success in order to create an independent, developed, just and prosperous Indonesia. The goal is explicitly stated that it will create clean, integrity, and other positive things. In this case there is a considerable challenge in realizing the objectives of the bureaucratic reform. The mindset and culture-set of bureaucrats have not fully supported an efficient, effective, productive and professional bureaucracy. Bureaucrats at each level have not really had a mindset that serves the community, have not achieved good performance (better performance) and have not been oriented to results (outcomes). ${ }^{44}$ Reforming government bureaucracy is impossible to do without being preceded by the government's efforts to evaluate or research government institutions. From this evaluation, a recommendation will be made on which organizational institutions will be effective and which ones should be saved, or which institutions will be formulated effectively. ${ }^{45}$

The government in this case issued several standards for efforts to reform the bureaucracy. Standardization includes the following: standardization of public services based on community involvement, rationalization of organization and development, integrating administration of business licensing services, structuring governance of government agencies, application of virtual office applications (eoffice), open recruitment and promotion of apparatus, repairs remuneration as leveraging apparatus management, developing apparatus resources through the assessment center, developing performance measurement with balanced scorecard, and free of corruption through an effective integrity zone. ${ }^{46}$

Bureaucratic reform is indeed a must. In the midst of a crisis of public trust, the government must seriously solve this problem. To encourage these ideas must be supported by every element, both government, legislature, judiciary and society. To realize a good bureaucracy, there must also be good legal control. But in fact, the law can be a shield for them to realize their interests. So it's no wonder the general expression in society, the law is sharp down but blunt up. Nurlaialatul Musyafa'ah said that the law which became the role model of society was a social ideal that would never stop being pursued until the end of life. Therefore, humans always hope for the

\footnotetext{
${ }^{43}$ Yunairi, Hakim, and Prasojo, Pemimpin dan Reformasi Birokrasi, ix- $\mathrm{x}$.

${ }^{44}$ Yunairi, Hakim, and Prasojo, Pemimpin dan Reformasi Birokrasi.

${ }^{45}$ Thoha, Birokrasi pemerintah Indonesia di era Reformasi, 11.

${ }^{46}$ Kementerian Pemberdayaan Aparatur Negara dan Reformasi Birokrasi, 'Reformasi Birokrasi', 107.
} 
following: a) Benefit of life for yourself and others; b) The uprightness of justice, the guilty person must get the right punishment and the innocent get good and right legal Protection; c) Equal rights and obligations in law. The law does not discriminate for any reason; d) Mutual control in the community, so that the establishment of the law can be realized by the community itself, such as the existence of an environmental security system; e) Freedom of expression, argues, acts without exceeding the limits of law and social norms and f) Positive social regeneration and responsibility for the future of social life and the life of the nation and state. ${ }^{47}$

Muslims as the majority people in this country must implement Islamic values. The purpose of the prescription (maqasșid syari'ah) of Islam is to realize the benefit of muslims and other people, even for the universe (rahmatan lil 'älaminn). This is because Maqāșid Syari'ah has two dimensions, namely the divine dimension and the human dimension. Sharia which originates in the Qur'an and Sunnah aims at the benefit of humans. Sharia guides humans to attain ultimate happiness, not only in the world but also through the heavens to achieve the highest eternal values in the hereafter. ${ }^{48}$

Solving the problem of integrity in this case, the bureaucracy must be resolved by referring to the applicable laws and regulations. In order to avoid conflict, this is where the importance of hifzu al-ummah is able to maintain the harmony and tranquility of a nation. ${ }^{49}$ La Jamaa in his research revealed that the concept of Islamic law contained in sharia is not only transcendent but also profane. So this concept is an integration between divine and humanist values. Thus, even though maqāșid syari'ah is of divine dimension but also sharia is revealed to humans not for the benefit of God, but for the benefit of mankind itself. ${ }^{50}$

The implementation of maqassid syaritah in the life of the state especially regarding bureaucracy is measured into three categories. First, maqașid aḍ-daruriyat, which is a basic human need that is primary. When this need is not able to be realized it will damage human life in the world and in the hereafter. Second, maqāssid al-hājiyat is a secondary human need. This second level is intended to eliminate difficulties in human life. The failure of this level does not end up damaging human life but will make it difficult. Third, maqāsid at-tahsiniyat is a tertiary human need. ${ }^{51}$ The bureaucratic problems that occur in Indonesia according to the author are at the level of maqāssidal-hajiyat. That is, these problems are very difficult for human life, even those who are harmed not only the community but also the country itself. This is in line with A. Djazuli as he said that:

The creation of a peaceful life among mankind is dharuriyah. Hajjiyah is an effort to resolve conflicts, such as agreements, which are collective agreements and

\footnotetext{
${ }^{47}$ Nur Lailatul Musyafaah, 'Pemilihan Umum Kepala Daerah Serentak Perspektif Maqasid AlSyariâ $€^{\mathrm{TM}}{ }_{a h}$, Al-Daulah: Jurnal Hukum dan Perundangan Islam 6, no. 2 (1 October 2016): 392, https://doi.org/10.15642/ad.2016.6.2.369-395.

${ }^{48}$ Q.S. An-Nahl: 60.

${ }^{49}$ Maimunah Maimunah, 'Politik Islam Perspektif Maqashid Syariah', El-Mashlahah 8, no. 1 (2018): 21, https://doi.org/10.23971/el-mas.v8i1.1093.

50 La Jamaa, 'I Jamaa', Asy-Syir'ah: Jurnal Ilmu Syari'ah dan Hukum 45, no. 2 (2011), https://doi.org/10.14421/asy-syir'ah.2011.\%x.

${ }^{51}$ Ahmad, 'Hukum Aborsi Akibat Perkosaan (analisis Hukum Islam Terhadap Peraturan Pemerintah Nomor 61 Tahun 2014 Tentang Kesehatan Reproduksi )', 170-71.
} 
must be followed together. The tahsiniyah is deeds in the form of morality of alkarimah towards fellow human beings. ${ }^{5253}$

Although being at the level of al-häjiyat does not mean it is not important. The complicated bureaucracy is very detrimental to many parties. In the end justice cannot be realized, only certain circles can enjoy excellent service. This does not mean that the bureaucracy in this country is all bad, but in general this is often found in almost all regions, both local, regional and even national levels. Wahab Afif in this case uses the term maslahat al-ummah. This term is actually in line with the intent of hifzu al-ummah A. Djazuli. In his methodological framework, Wahab Afif explained the efforts that could be made to realize the benefit of the people as follows: 1) The main effort is how to produce quality (pious) individuals. Academically, it is done by instilling the values of worship with the muqaranah approach in order to be tolerant and respect for diversity; 2) If godly individuals have materialized, it will also manifest a sakinah, harmonious and happy family. ${ }^{54}$ Academically, it is necessary to instill deep family figh values to achieve a healthy family; 3) From sakinah families there will be people who are marhamah (love each other). Communities that help each other, remind each other about truth and justice, ${ }^{55}$ and when a dispute or conflict occurs it can refer to the Qur'an and Sunnah. ${ }^{56}$ Academically, it is necessary to instill the values of muamalah fiqh and social fiqh.

In order to ensure the continuity of peace in society, the state must be present which serves to create equal distribution of physical and spiritual welfare. A country which is capable of realizing baldatun tayyibatun wa rabbun gafur, ${ }^{57}$ carrying out the mandate properly as a manifestation of state responsibility for the lives of its people. ${ }^{58}$ Academically, realizing it all by planting Siyasah jurisprudence oriented to hifzu alummah. $^{59}$ The idea of A. Djazuli about hifzu al-ummah is not yet perfect. He only voiced this brilliant idea and then studied it more deeply and continued to develop. He said that his thoughts on hifzu al-ummah were a preliminary study which he put into maqāsid syarīah. Further and specific studies require knowledge of the vast and profound Islamic poetry, both in terms of substance and methodology. ${ }^{60}$

The age development continues to move dynamically. The emergence of the 4.0 industrial revolution, which soon emerged in the era of society 5.0 was evidence of developments that cannot be ignored. The era of society 5.0 was initiated by Japan with the concept of human-centered society and technology-based. This concept was initiated to replace the 4.0 industrial revolution which was considered to have the potential to degrade the role of humans. ${ }^{61}$ The concept of hifzu al-ummah in overcoming the problem of bureaucracy in Indonesia must follow this development.

\footnotetext{
${ }^{52}$ Djazuli, Fiqh Siyasah, 264.

${ }^{53}$ A. Djazuli, Fiqh Siyasah, 264.

${ }^{54}$ Q.S. Ar-Rum: 21.

${ }^{55}$ Q.S. A1-'Ashr: 1-3.

${ }^{56}$ Q.S. An-Nisa: 59.

${ }^{57}$ Q.S. Saba': 15.

${ }^{58}$ Q.S. An-Nisa: 58.

${ }^{59}$ Praja, Teori Hukum Dan Aplikasinya, 165-66.

${ }^{60}$ Djazuli, Fiqh Siyasah, 265.

61 'Mengenal Society 5.0, Transformasi Kehidupan Yang Dikembangkan Jepang | TIMES Indonesia', accessed 29 June 2020, https://www.timesindonesia.co.id/read/news/197889/mengenal-society50transformas\%20i-kehidupan-yang-dikembangkan-jepang.
} 
Convoluted bureaucracy can be overcome by transforming conventional systems into modern systems such as artificial intellegence. Thus the obstacles in the problem of bureaucracy can slowly be overcome. Indeed, there have been alluded to in the government's strategic program as outlined above, but it must be more serious with more systematic steps that can be maximized massively. This concept can be implemented in the form of good governance. The State Adminsitration Institute in Arif Cahyadi concluded nine fundamental aspects to realize good governance. Thera are participation, rule of law, transparancy, responsiveness, consesus orientation, equality, effectiveness and effecien, accuntability and strategic vision. ${ }^{62}$ To realize this, thera are five factors that influence it, firstly the ability of human resources in a professional government apparatus. Second, the availability facilities and infrastructure. Third, high responsibility of government apparatus. Fourth, the availability of adequate public information. Fifth, the rules are enforced fairly and equally. ${ }^{63}$

\section{Conclusion}

Bureaucracy is a system of government that deals with public services. Bureaucracy in Indonesia has always gotten a negative stigma from both local communities and foreign communities. Nations in the world have been preoccupied with new ideas in the form of the era of society 5.0, while the nation is still trying to release the entangled bureaucracy. The government's efforts in reforming the bureaucracy with its various standards have not been able to produce satisfactory results. Maqāșid syarī'ah has been too oriented to individual issues, so that it is less concerned about humans in the community. Hifzu al-ummah as the development of maqāșid syarīah places this bureaucratic problem in the category of maqāșid al-hājiyat. The complicated bureaucracy does not damage human life but is very difficult. The bureaucratic system in Indonesia must be directed at a modern system with artificial intelligence in welcoming the era of 5.0 society. In essence, this era wants a balance of roles between humans and technology. So that both can run more effectively and efficiently. Technically, the integration of this concept cannot yet be described, but it is a sustainable first step by opening up other research opportunities.

\section{Bibilography}

Afdal. 'Berikut Data Kasus Korupsi dari 2018 Hingga Maret 2019'. Fajar Indonesia Network (blog), 1 April 2019. https://fin.co.id/2019/04/01/berikut-datakasus-korupsi-dari-2018-hingga-maret-2019/.

\footnotetext{
${ }^{62}$ Arif Cahyadi, 'Penerapan Good Governance Dalam Pelayanan Publik (Studi Tentang Kualitas Pelayanan Elektronik Kartu Tanda Penduduk Berbasis Good) Governance Di Kecamatan Sukolilo Surabaya)', JPAP: Jurnal Penelitian Administrasi Publik 2, no. 02 (2016): 481, https://doi.org/10.30996/jpap.v2i02.1004; Muhammad Amirul Haq Muis, Hasrat Arief Saleh, and Muhammad Rusli, 'Analisis Implementasi Good Governance Dalam Pelayanan Publik Di Kecamatan Panakukkang Kota Makassar', GOVERNMENT: Jurnal Ilmu Pemerintahan 7, no. 2 (27 December 2016): 77.

${ }^{63}$ Sondil E. Nubatonis, Sugeng Rusmiwari, and Son Suwasono, 'Implementasi Prinsip-Prinsip Good Governance Dalam Meningkatkan Kinerja Organisasi Pelayanan Publik', JISIP: Jurnal Ilmu Sosial Dan Ilmu Politik 3, no. 1 (2014): 18.
} 
Ahmad, Afrizal. 'Reformulasi Konsep Maqashid Syar'iah; Memahami Kembali Tujuan Syari'at Islam Dengan Pendekatan Psikologi'. Hukum Islam 14, no. 1 (2014): 45-63. https://doi.org/10.24014/hi.v14i1.988.

Ahmad, Sabarudin. 'Hukum Aborsi Akibat Perkosaan (analisis Hukum Islam Terhadap Peraturan Pemerintah Nomor 61 Tahun 2014 Tentang Kesehatan Reproduksi )'. El-Mashlahah 8, no. 2 (2018). https://doi.org/10.23971/elmas.v8i2.1321.

Al-Qaradhawi, Yusuf. Fiqh Maqashid Syariah ; Moderasi Islam Antara Aliran Tekstual Dan Aliran Liberal. Translated by Arif Munandar Riswanto. Jakarta: Pustaka al-Kautsar, 2014.

Asikin, Zainal, and Amiruddin. Pengantar Metode Penelitian Hukum. Jakarta: Rajawali Pers, 2013.

Bakri, Asfari Jaya. Konsep Maqasid Al-Syari'ah Menurut al-Syatibi. Jakarta: RajaGrafindo Persada, 1996.

Cahyadi, Arif. 'Penerapan Good Governance Dalam Pelayanan Publik (Studi Tentang Kualitas Pelayanan Elektronik Kartu Tanda Penduduk Berbasis Good) Governance Di Kecamatan Sukolilo Surabaya)'. JPAP: Jurnal Penelitian Administrasi Publik 2, no. 02 (2016). https://doi.org/10.30996/jpap.v2i02.1004.

Dedi, Syahrial. 'Perluasan Teori Maqashid Al-Syari'ah: Kaji Ulang Wacana Hifdz Al-'Ummah A. Djuzuli | Dedi | Al-Istinbath : Jurnal Hukum Islam'. Al Istinbath Jurnal Hukum Islam 1, no. 1 (2016). http://dx.doi.org/10.29240/jhi.v1i1.72.

Djazuli, A. Fiqh Siyasah: Implementasi Kemaslahatan Ummat Dalam Rambu-Rambu Syariah. Jakarta: Kencana, 2013.

Emzir. Analisis Data: Metodologi Penelitian Kualitatif/ Emzir. Jakarta: Rajawali Press, 2010.

Fadhil, Haris. 'Cicil Hukuman USD 7,3 Juta, Berapa Sisa "Utang" Novanto ke Negara?' detiknews. Accessed 29 June 2020. https://news.detik.com/berita/d-4297856/cicil-hukuman-usd-73-jutaberapa-sisa-utang-novanto-ke-negara.

Fatkhuri, Fatkhuri. 'Korupsi Dalam Birokrasi Dan Strategi Pencegahannya'. Jurnal Ilmiah Manajemen Publik Dan Kebijakan Sosial 1, no. 2 (16 April 2018): 65-76. https://doi.org/10.25139/jmnegara.v1i2.784.

Gabrillin, Abba. 'Sejak 2012, Ada 20 Hakim Tersangkut Kasus Korupsi'. KOMPAS.com. $\quad$ Accessed $29 \quad$ June 2020. https://nasional.kompas.com/read/2019/05/07/10483411/sejak-2012-ada20-hakim-tersangkut-kasus-korupsi.

Haboddin, Muhtar-, and Ahmad Imron Rozuli. 'Birokrasi, Korupsi, Dan Kekuasaan'. Jurnal Transformative 3, no. 1 (22 March 2017): 1-14.

Haning, Mohammad Thahir. 'Reformasi Birokrasi di Indonesia: Tinjauan Dari Perspektif Administrasi Publik'. JAKPP (Jurnal Analisis Kebijakan \& Pelayanan Publik) 4, no. 1 (12 January 2019): 25-37. https://doi.org/10.31947/jakpp.v4i1.5902.

Indiahono, Dwiyanto. Birokrat [Bukan] Pelayan Koruptor: Telaah Korupsi, Demokrasi Dan Pro-Poor Policy Di Era Reformasi. Jakarta: Gava Media, 2016.

Jamaa, La. 'I Jamaa'. Asy-Syir'ah: Jurnal Ilmu Syari'ah dan Hukum 45, no. 2 (2011). https://doi.org/10.14421/asy-syir'ah.2011.\%x. 
Kementerian Pemberdayaan Aparatur Negara dan Reformasi Birokrasi. 'Reformasi Birokrasi'. Kementerian Pendayagunaan Aparatur Negara dan Reformasi Birokrasi. $\quad$ Accessed 29 June 2019. https://www.menpan.go.id/site/reformasi-birokrasi/makna-dan-tujuan.

Kementerian Pendidikan dan Kebudayaan. 'Arti Kata Birokrasi'. Accessed 29 June 2020. https://kbbi.kemdikbud.go.id/entri/birokrasi.

- 'Arti Kata Umat'. Accessed 29 June 2020. https://kbbi.kemdikbud.go.id/entri/birokrasi.

Maimunah, Maimunah. 'Politik Islam Perspektif Maqashid Syariah'. El-Mashlahah 8, no. 1 (2018). https://doi.org/10.23971/el-mas.v8i1.1093.

Martini, Rina. Buku Ajar Birokrasi Dan Politik. Semarang: LPPMP Universitas Diponegoro, 2012.

'Mengenal Society 5.0, Transformasi Kehidupan Yang Dikembangkan Jepang I TIMES Indonesia'. Accessed 29 June 2020. https://www.timesindonesia.co.id/read/news/197889/mengenal-society50transformas\%20i-kehidupan-yang-dikembangkan-jepang.

Muis, Muhammad Amirul Haq, Hasrat Arief Saleh, and Muhammad Rusli. 'Analisis Implementasi Good Governance Dalam Pelayanan Publik Di Kecamatan Panakukkang Kota Makassar'. GOVERNMENT: Jurnal Ilmu Pemerintahan 7, no. 2 (27 December 2016): 73-82.

Mustafa, Delly. Birokrasi Pemerintahan. Bandung: Alfabeta, 2013.

Musyafaah, Nur Lailatul. 'Pemilihan Umum Kepala Daerah Serentak Perspektif Maqasid Al-Syariâ $€^{\mathrm{TM}}$ ah'. Al-Daulah : Jurnal Hukum dan Perundangan Islam 6, no. 2 (1 October 2016): 369-95. https://doi.org/10.15642/ad.2016.6.2.369395.

Paat, Yustinus. 'Ini Enam Penyakit Birokrasi Di Indonesia'. Accessed 29 June 2020. https://www.beritasatu.com/nasional/485766-ini-enam-penyakit-birokrasidi-indonesia.

Praja, Juhaya S. Teori Hukum Dan Aplikasinya. Bandung: Pustaka Setia, 2011.

Pramuka, Gatot. 'Masalah Birokrasi Sebagai Pelayan Publik'. Masyarakat, Kebudayaan Dan Politik 20, no. 1 (2007).

Rachman, Dylan Aprilialdo. 'ICW: Kerugian Negara Akibat Korupsi Pada 2018 Capai Rp 9,29 Triliun'. Accessed 29 September 2019. https://nasional.kompas.com/read/2019/04/28/15294381/icw-kerugiannegara-akibat-korupsi-pada-2018-capai-rp-929-triliun?page=all.

Reflita, Reflita. 'Eksploitasi Alam dan Perusakan Lingkungan (Istinbath Hukum atas Ayat-Ayat Lingkungan)'. SUBSTANTIA: Jurnal Ilmu-Ilmu Ushuluddin 17, no. $2 \quad$ October $11 \quad 2015)$ : 147-58. https://doi.org/10.22373/subtantia.v17i2.4101.

Romli, Lili. 'Masalah Reformasi Birokrasi'. Civil Service Journal 2, no. 2 November (2008). https://jurnal.bkn.go.id/index.php/asn/article/view/149.

Rozi, Syafuan. Zaman Bergerak, Birokrasi Dirombak: Potret Birokrasi Dan Politik Di Indonesia. Yogyakarta: Pustaka Pelajar, 2006.

Saputra, Ari. 'Indonesia Ranking 89 Indeks Persepsi Korupsi Dunia'. detiknews. Accessed 29 June 2020. https://news.detik.com/foto-news/d4405951/indonesia-ranking-89-indeks-persepsi-korupsi-dunia. 
Setiawan, Irfan. 'Mengikis Perilaku Korupsi Pada Birokrasi Pemerintahan'. Jurnal Ilmu Pemerintahan Widya Praja 42, no. 1 (1 June 2016): 29-29. https://doi.org/10.33701/jipwp.v42i1.140.

Soekanto, Soerjono, and Sri Mamudji. Penelitian Hukum Normatif. Jakarta: RajaGrafindo Persada, 2003.

Sondil E. Nubatonis, Sugeng Rusmiwari, and Son Suwasono. 'Implementasi PrinsipPrinsip Good Governance Dalam Meningkatkan Kinerja Organisasi Pelayanan Publik'. JISIP: Jurnal Ilmu Sosial Dan Ilmu Politik 3, no. 1 (2014).

Thoha, Miftah. Birokrasi pemerintah Indonesia di era Reformasi. Jakarta: Kencana, 2011. Widowati, Hari. 'Proyek Reklamasi Gurindam 12 Yang Menjerat Gubernur Kepri Berita Katadata.Co.Id'. Accessed 29 June 2020. https://katadata.co.id/berita/2019/07/11/proyek-reklamasi-gurindam-12yang-menjerat-gubernur-kepri.

Widyastuti, Anastasia Reni. 'Disfungsionalisasi Birokrasi Sebagai Kendala Dalam Pemberantasan Korupsi'. Yustisia Jurnal Hukum 4, no. 3 (1 December 2015): 683-99. https://doi.org/10.20961/yustisia.v4i3.8700.

Widyawati. 'Hifz Al-Ummah Sebagai Tujuan Syariah: Kontribusi Pemikiran Hukum Islam Prof. a. Djazuli'. In The Contribution of Indonesia Islam to The World Civilization. IAIN Raden Intan Lampung, 2016. http://iainsurakarta.ac.id/aicis/2016/paralel-sessions/.

Yunairi, Rusfi, Abdul Hakim, and Eko Prasojo. Pemimpin dan Reformasi Birokrasi: Catatan Inspiratif dan Alat Ukur Kepemimpinan dalam Implementasi Reformasi Birokrasi. Jakarta: Kementrian Pendayagunaan Aparatur Negara dan Reformasi Birokrasi, 2013.

Yusriadi, Yusriadi. 'Reformasi Birokrasi Indonesia: Peluang dan Hambatan'. Jurnal Administrasi Publik: Public Administration Journal 8, no. 2 (21 December 2018): 178-85. https://doi.org/10.31289/jap.v8i2.1824. 